\title{
JEGA MARKET
}

I

Osuman Dan Fodio, the Shehu (Sheikh) who established Fula ${ }^{1}$ dominion 120 years ago over so great a part of the Western Sudan, numbered amongst his early disciples a turbulent character named Abdu Salame, a Hausa of the tribe of Ariwa Mantu, and a man of reputed sanctity. Abdu Salame was a cause of the final breach between the Shehu and Yunfa Sarkin Gobir. Incurring the enmity of Yunfa, he and his followers were compelled to seek safety in flight. Entering Gimbana they fortified the town and defied the Sarkin Gobir. Their resistance was unsuccessful; Gimbana fell and many prisoners were taken. While these were on their way to Yunfa the Moslems amongst them were released by the Shehu, who by that time had acquired considerable influence. The repeated demands of Yunfa for the surrender of the prisoners were met with refusals, and this led to the break between the Shehu and the Sarkin Gobir which precipitated the jihad. When the time came for the victorious Shehu to choose governors for his extensive dominions, his Hausa disciple, Abdu Salame, was put in charge of a considerable district. After a while the turbulent spirit of Abdu began to assert itself. Finally he abjured Islam and openly rebelled against the Shehu, and, we are told, it was at a place called Jega that he and his followers offered a long and successful resistance to the Fula. He was finally defeated and died a fugitive. He and his followers and their descendants are known as Gimbanawa, and Jega is to-day their principal town. Bohari, the son of Abdu Salame, was the first Sarkin of Jega.

\footnotetext{
I NorI BY EDITors.-The author adopts throughout this articlo the Arab rendering "Fillani" for the Fula people. The Hansa name for this remarkable race is "Fellata." But it has been thought best to use but one term-Fula-to indicato this nearly half-white, ancient, hybrid stock, originating in West Africa. Throughout their range their own name for themselves is Pal-o in the singular and Fal-be in the plural; and the Mandingo peoples intervening between them and the Senegambian coast generally speak of them as the "Fula."
} 


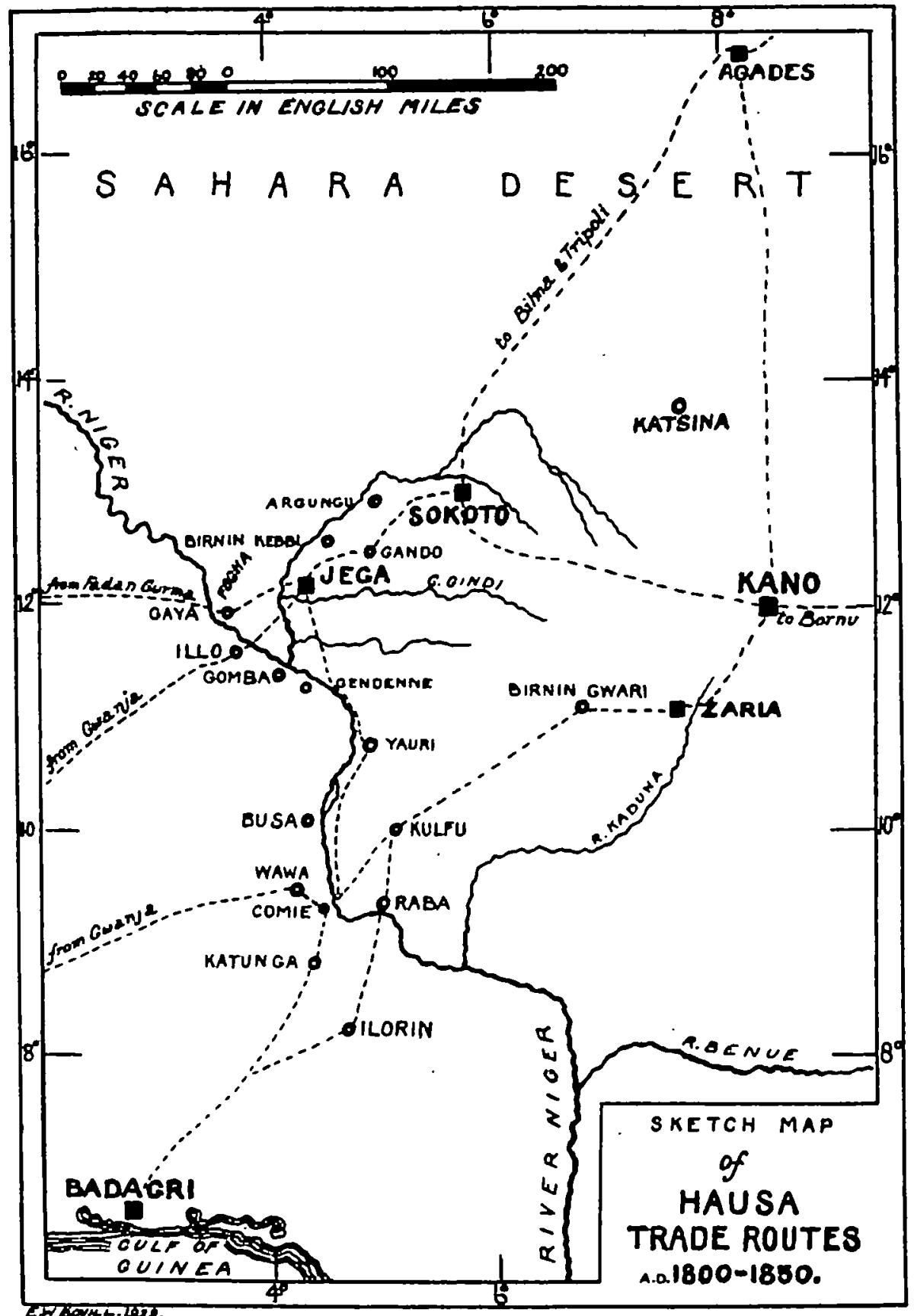

To fect 5 


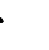


In August, 1854, Dr. Barth found himself for a second time within a few miles of Jega, but on account of the bad state of the roads he was prevented from carrying out his intention of visiting the town. He tells us it was " the important place which .... on account of its mercantile importance, had attracted attention in Europe a good many years ago "; he adds that although it had declined from its former importance, it was of sufficient consequence to make him desirous of visiting it. Careful search has failed to reveal how and when Jega came to attract attention in Europe at a period when so little was known of this part of the interior of Africa. It was presumably subsequent to Clapperton's second visit to Sokoto, in I826, for, although one of the principal objects of his journey was to acquaint himself thoroughly with the trade of the countries through which he travelled, neither he nor his servant, Richard Lander, mentioned the name of Jega in their journals.

Although, according to Barth, Jega had already lost much of its importance as far back as I854, and, to our certain knowledge, its fortunes have been declining for the last twenty years, it is to-day the largest native market in the Northern Provinces of Nigeria with the sole exception of Kano. The building of railways by the British and French and the consequent diversion of trade into new channels have been sapping the strength of Jega for some years and the decline in its prosperity has recently become so marked that it seems not unlikely that it may once again sink back into the obscurity from which it emerged less than a century ago. This perhaps is sufficient excuse for an attempt to discover the secret of its rise to prosperity and fame.

\section{II}

Jega lies in the extreme west of the Hausa country, which from the earliest times has been a region of great commercial activity; as it appears to have attained the height of its fame in the first half of last century, it will be pertinent to review briefly the trade of the Hausa people a hundred years ago. Although there is a tendency to exaggerate the extent of the foreign trade of the Hausawa, there is no doubt that their 
commercial relations with the outside world were remarkably extensive for a negroid people inhabiting a country so far removed from the sea, and pressed between the boundless wastes of the Sahara and the well-nigh impenetrable forests of the tropical rain belt. Their foreign trade extended northward to the coast of Tripoli and southward to the Gulf of Guinea; they maintained commercial intercourse with Timbuktu and carried on a very considerable trade with the less distant saltbearing regions of Bilma in the north, Bornu (Chad) in the east and Fogha on their western frontier.

The Mediterranean and Guinea coasts were connected by a great trunk route which passed through the centre of the Hausa States. From Tripoli it extended due south across the Sahara, entering the Sudan in Bornu near Lake Chad; from there it continued westward to Kano, at all times the greatest market of the interior, whence it ran southward across the Niger and through the Yoruba forests to Badagri, the trading port of the Slave Coast, situated not many miles west of the modern port of Lagos. A hundred years ago the European slave trade still flourished and Badagri was the most important town on the West Coast of Africa. It was divided into British, Spanish, Portuguese and French quarters and there was a considerable Hausa colony. Hausa traders, too, carried on a very extensive trade with Gwanja in the hinterland of the Gold Coast, the most important of the kola-nut districts. It is interesting to note that the Arab merchants of Tripoli were trading indirectly with the markets of the Guinea coast in at least three articles. Kola nuts grown in the coastal regions were carried all the way to Tripoli, where they were sold for as much as two dollars a score; great quantities of glass beads of Venetian manufacture and unwrought silk found their way from Tripoli to Badagri and Gwanja.

The importance of this trunk route was due mainly to the fact that it carried the bulk of the foreign trade of Kano and other Hausa markets. The traffic with Tripoli in slaves alone was enormous; they were exchanged in Kano for swordblades, fire-arms, scents and spices. Tuareg from the Sahara coming south with the salt of Bilma returned with their camels laden with corn and cloth. A big trade in natron from Lake 
Chad was carried on with Bornu. The salt trade of Fogha was in the hands of the Hausawa. From Badagri came traders with all manner of European trade goods-mostly cloth, brass and pewter-which they bartered for slaves, as well as for the wares of Hausa craftsmen and the beads and coarse silk of Tripoli. But no trade was more flourishing than that with Gwanja, for the kola nut had gained such a hold on the people that it tended to become a necessity rather than a luxury.

There appears to have been no well-defined route between Kano and Badagri. Between these two places lay a region of dense bush peopled by a variety of different tribes, often at war with each other, and numerous petty states constantly in a condition of political instability. Any road which lay through this turbulent and lawless region was liable to be closed to traders at frequent intervals by all manner of disturbances. Consequently we find trade following no well-defined route, but flowing through many and devious channels. In the accounts of the early explorers the weary traveller is often compelled to retrace his steps for a long distance to seek another and less dangerous road.

The disturbed state of the country was only one of the obstacles which impeded the traveller and hampered trade. Circumstances compelled traders to travel together in large bodies for mutual protection, and caravans thus formed sometimes numbered several thousand souls, besides all manner of pack animals. For these huge caravans the crossing of a river as big as the Niger was an undertaking not to be lightly carried out at any chance point on the river bank. The riverine tribes had established ferries at convenient points and levied tolls on those making use of them. The traffic being considerable, the ferries proved lucrative to their proprietors, who did their utmost to foster trade by guaranteeing comparative security to travellers through such of the country as they controlled. In the early years of the nineteenth century the two principal ferries were at Raba, just below the present bridge at Jebba, and at Komie, about fifty miles higher up.

The uncertain route of a Hausa trader returning from $\mathrm{Gwanja}$ to Kano may be compared with the sea-passage of medixval pilgrims travelling from the Continent to Canterbury. Having 
once cast off from the French coast, the frail craft of the pilgrims might make the coast of England anywhere between the Solent and the Nore; it little mattered to the pilgrims at what port they landed so long as it took them to the sacred shrine of Becket. Similarly, the Hausa trader cared little whether he was cast up from the turbulent bush at Raba or at Komie so long as he got his precious kolas across the Niger and his feet set safely on the road to Kano.

From the ferry at Komie one road ran north-east through Birnin Gwari and Zaria to Kano, but another well-known route followed up the left bank of the Niger through Yauri and into the north-western districts of Hausa, where it converged on an important kola route running in a north-easterly direction from Gwanja. The latter was an alternative route from the Gold Coast to Kano, the crossing of the Niger being effected probably at Illo or in the neighbourhood of Gaya. These two, with a third coming from Wagadugu and Fadan Gurma, were the chief trade routes of the west; they converged and met in the valley of the Gulbin Gindi, probably at or near Jega, which, a hundred years ago, was emerging from a period of strife and acquiring commercial instead of political fame.

\section{III}

Jega has one remarkable feature in common with six other of the most noted markets of the Western Sudan. These six are Bamako, Wagadugu, Fadan Gurma, Gayạ, Kano and Dikwa, which, with Jega, are all situated within a day's march of the twelfth parallel of north latitude. It is not by mere chance that we find them so. The twelfth parallel is roughly the latitude of the intermediate zone which intervenes between the savannas of the Sudan and the forests of the tropical rain belt; it separates the oil palms of the forests from the borassus and hyphane palms of the Sudan, and it marks the southern limit of the date palm, which in this region is not often found and is usually barren.

The forests were peopled by predatory negro tribes practising the gloomy rites of fetishism and dominated by the awful power of the fetish priests. Although many of the coastal. 
tribes had for centuries been in constant touch with Europeans, they had derived no benefit from a contact which was maintained solely through the unwholesome medium of the slave trade. The comparatively open plains of the Western Sudan were the home of negroid tribes which had been raised to a higher cultural level by an infusion of Hamitic blood and by the numerous beneficial influences-among which we must include a fairly general conversion to Islam-which had percolated into their country by way of the caravan routes of the Sahara and up the Nile valley into the Eastern Sudan. Although paganism was practised amongst these negroid tribes-to this day many of the old pagan rites survive amongst professed Moslems - they heartily despised the more primitive peoples of the forests, and regarded with abhorrence the revolting rites which often characterised their religious practices. From time immemorial it had been the custom of the Sudan tribes annually to raid the forest tribes for slaves. The conversion to Islam of the former added religious fervour to the zeal of the raiders, and as years went by there was a tendency for these annual raids to become more highly organised and to be conducted on an ever-increasing scale. Consequently we find that at all times there was distrust and hatred between the tribes of the Sudan and those of the coastal forests.

Happily there was a certain amount of peaceful intercourse through the medium of trade. Most of the forest tribes, who were constantly at war among themselves, lacked that prime necessity, salt, and unless they were on friendly terms with the tribes on the sea-coast, which they usually were not, they could only procure it from the north. The Sudan tribes were-able to provide salt from various sources, and were willing to barter it for gold-dust, kola nuts, slaves, or European goods traded up from the coast. The trade varied locally, but from the Gambia in the west to Lake Chad in the east there was considerable commercial intercourse between the hostile tribes of the savannas and the forests. This trade gave rise to numerous entrepots for trade in the intermediate zone-that is to say, in the latitude of $12^{\circ} \mathrm{N}$.-where the forest tribes could safely barter their goods for the salt of the Sudan peoples. The most famous of these estrepots were Bamako, Wagadugu, Fadan Gurma, 
Gaya, Jega and Dikwa. Although Kano, too, actually lies on the twelfth parallel, its position is exceptional, for it is typically a Sudan market, and its commercial importance is based on the remarkable industry of the Hausa people rather than on the convenience of its position as an entrepot; moreover, owing to the elevation of the country around Kano, the savannas of the Sudan here extend considerably south of $12^{\circ} \mathrm{N}$.

The country around Jega presents all the characteristics of the intermediate zone. To the north lies savanna or orchard bush and to the south the forests, which, however, do not attain great density till the coastal region is approached; around is bush of moderate density, but no longer of the orchard type, while the watercourses are characterised by gallery forest, though this is fast disappearing as the cultivable areas are extended. A few oil palms and occasional groves of bananas bear witness to a comparatively humid climate. Belts of borassus, or fan palms, are numerous in the north, where also may be found very occasional hyphere and date palms, the latter stunted and barren.

\section{IV}

The modern Gimbanawa are an unprogressive people who profess Islam, but their creed rests lightly upon them, and they are not without pagan sympathies. They appear to be endowed with no outstanding virtues, with the exception of a certain skill in tanning, and they are not known to possess any commercial ability, the bulk of their trade being in the hands of foreigners. The breadth and elasticity of their religious views, however, may be accounted an asset in a market which serves as an entrepot for the trade of both Moslems and pagans. Their principal occupations are agriculture, tanning and weaving. The important position which this market rose to occupy cannot be said to be due to any special virtue or effort of the Gimbanawa, but rather to the chance of circumstances.

As regards transport Jega is singularly well situated and is equally accessible to tribes of the north and of the south. It enjoys the great advantage of being situated on the Gulbin Gindi at the highest point which can be used by large canoes 
all the year round, so that it is at all times accessible from the Niger by a navigable waterway, the big market of Gomba being at the confluence of the two rivers. The neighbourhood is happily free from tsetse fly, and the market may therefore be safely visited by the various kinds of transport animals in use in the Sudan. It has a bad reputation amongst Buzai camel-men, but a few of their animals may be found in the market during the dry season.

Besides these advantages Jega was geographically well placed to attract foreign trade before the British and French railways began to penetrate into the interior. Not only was it linked to the Niger by a perennially navigable waterway, but seventy miles southward was the independent pagan state of Illo with an important ferry across the Niger, ${ }^{1}$ and just above and below the big markets of Gaya and Gomba. It lay at the junction of two important trade routes of the south, the one coming up from Badagri on the Slave Coast and the other from Gwanja. Only three or four days' march to the west lay the great salt-bearing district of the Dallol Fogha, with an annual output of about 700 tons of salt, for which Jega was the natural market. Communication with Kano, the greatest trade centre of Western Africa, was maintained by a well-known route which was one of the principal highways of the Fula dominions. The salt mines of Bilma were accessible by way of Agades (Air), by which route came also the unwrought silk of Tripoli, for which Jega was the principal market in the time of Barth. A market endowed with so many natural advantages could hardly fail to attain a position of importance.

\section{V}

Although the Hausa States offered but feeble resistance to the Fula, they no sooner began to feel the weight of the yoke of

\footnotetext{
1 Whether the important modern ferry at Gendenne was also in use a century ago appears doubtful. As Gendenne itself is known to have been a place of some importance, possibly it was. The heavy traffic which this ferry now carries is principally restricted to the flourishing cattle trade between Jega and Lagos, which is of recent growth.

- So important was this trade that in 1808 Bello, the Shehu's son, arranged a treaty with the Sarkin AIr for keeping open the trade routes.
} 
the conqueror than they tried to free themselves by armed rebellion. The early years of Fula dominion were a period of turbulence, and it cannot be said that they were firmly established till shortly before the death, in I837, of Muhammadu Bello, the successor of the Shehu. By that year the greater part of what to-day comprises the Northern Provinces of Nigeria, besides much country lying to the west, had become tributary to the Fula Sultans. Sokoto and Gando became the twin capitals, closely situated in the basin of the Gulbin Solsoto. the former eighty miles from Jega and the latter only thirty. Sokoto, however, the original capital of Shehu, was by far the more important and became the political hub of this part of Africa, with a large and expanding population. ${ }^{1}$ Tribute from all parts of the Fula dominions came pouring in to Sokoto, and from it there radiated roads leading to all quarters. It became, temporarily, a centre of wealth and learning, and within its walls there resorted Arab merchants from Tripoli and learned malams from Masina.

Although part of the trade of Kano and other Hausa markets with Badagri, Gwanja and Tripoli was inevitably drawn into the populous valley of the Gulbin Sokoto, the city itself never acquired commercial importance. The capital of the Fula Sultans was too constantly disturbed by the clash of arms and the marshalling of troops to generate the tranquil atmosphere which is so necessary to trade; whilst the ardent fanaticism of the Fula, the flame of whose religious zeal continued to burn intermittently up to the present century, served only to repel the cosmopolitan crowd of small traders who throng the markets of the Western Sudan.

Moreover, even in the vicinity of Sokoto there was often little security for travellers on account of the warlike Kebbawa of Argungu. This people had thrown off the yoke of the Fula and founded an independent kingdon at Argungu. Although their capital lay within two or three days' march of both Sokoto and Gando, they maintained their independence up to the

\footnotetext{
1 In 1824 Sokoto appeared to Clapperton to be " the most populous town he had visited in the interior of Africa." As he had just como from Kano this is rarprising. The population of Sokoto to-day is about 21,000 , and that of Kano about 60,000 .
} 
British occupation in IgOr, and throughout the century they were constantly at war with the Fula, laying waste their lands and raiding up to the very walls of Sokoto.

With fanaticism within and turbulence without there was little enough to attract trade to Sokoto and Gando, but as they became the centres of a wealthy population there was need for a large and easily accessible market where the foreign trade of the country could be handled. This need was filled by Jega.

Formerly there had been another very important market in this district. This was the old and historical town of Birnin Kebbi. For two centuries or more the powerful and wealthy kingdom of Kebbi had been the centre of a very considerable foreign trade. In I805 the Fula captured Birnin Kebbi, and in the loot that followed a great deal of silver and some gold is said to have been taken.1 Birnin Kebbi is still a town of considerable size, but it never recovered its commercial prosperity. Although Jega was so well qualified by natural advantages to serve as an entrepot for trade, the opportunity to develop the commercial possibilities of its geographical position was provided by the unhappy destruction of this ancient kingdom of Kebbi. Many, indeed most, of the natural advantages with which Jega was so generously endowed were common also to Birnin Kebbi, and there can be little doubt that had this old and flourishing market of the powerful Kebbawa survived the jihad Jega could never have aspired to the important position which it rose to occupy.

VI

There has been a very decided decline in the fortunes of Jega during the last two decades. The extension of the Nigerian railway to Kano, the bridging of the Niger at Jebba, and the building of the Dahome railway by the French have combined to draw much trade away from the north-western provinces of Nigeria. At Sokoto there are now several European trading firms, whose activities have led to the growth of the

\footnotetext{
I In 1912 a groat of Edward III. of England was picked ap at Birnin Kebbi.
} 
Sokoto market at the expense of Jega. Moreover, the old fanatical hatred of the Fula for those less devout than themselves has practically died out under the equalising influence of British administration, and men of all creeds may to-day trade as freely within the walls of Sokoto as anywhere else.

Although the trade of Jega has been dwindling for some years it still occupies a commercial position second only to that of Kano. Its comparatively small population of about 10,000 includes many rich merchants, mostly natives of Lagos and the Gold Coast. On the outskirts of the town is the large marketplace comprising over four hundred stalls, built of clay with thatched roofs. Two big markets are held weekly, but there is a fair attendance daily except during the rains, when the trade of the whole country is at a standstill. Outside the town is a zango, or caravanserai, of over a hundred houses for traders who pay a small fee for a night's lodging, and here one may see all manner of natives, but they are mostly small Hausa traders. The trade in kola nuts continues to flourish, though on a reduced scale, and a good business is done in European trade goods. By far the most important trade is that with Lagos in cattle. The rapid growth of European and Moslem settlements on the coast has created a big demand for meat. The bulk of this trade passes through Jega and thence southward over the Niger at Gendenne. The following figures for the year I9I4I9I5 show the magnitude of this trade: cattle 83,592, sheep and goats (mostly sheep) 268,492 ; horses to the number of 3,956 were sold in the market during the same period, while the actual weight of goods brought into the market was estimated at 7,556 tons.

Although Jega is endowed with so many natural advantages, it seems probable that the ever-increasing extension of European commerce, with the subversive effect it has on native trade, will cause this once famous market to sink back into the obscurity from which it emerged less than a hundred years ago.

E. W. BoviLl. 